\title{
The Model of Relationship between the Perceived Values and the Purchase Behaviors toward Innovative Products
}

\author{
Shwu-Ing $\mathrm{Wu}^{1} \&$ Hui-Ling Chang ${ }^{1}$ \\ ${ }^{1}$ Department of Business Administration, National Chin-Yi University of Technology, Taiwan, R.O.C. \\ Correspondence: Shwu-Ing Wu, Department of Business Administration, National Chin-Yi University of \\ Technology, No. 57, Section 2, Zhongshan Road, Taiping, Taichung 411, Taiwan, R.O.C. Tel: 886-4-2392-4505.
}

Received: March 23, 2016

Accepted: April 19, 2016

Online Published: April 26, 2016

doi:10.5430/jms.v7n2p31

URL: http://dx.doi.org/10.5430/jms.v7n2p31

\begin{abstract}
As technologies have become ever innovative and mobile devices have become ever popular in recent years, most enterprises have been seeking innovation in their products to enhance the purchase intention of consumers and thus maintain their competitiveness. APPLE WATCH is one of such products. This study adopted the literature analysis and the empirical research to discuss the relevance among consumers' perceived values (functional value, emotional value, epistemic value, social value, and conditional value), attitudes, purchase intention and actual purchase behavior and analyzed the differences in the relations among all the perspectives between those who had other APPLE products and those who did not.

Through a questionnaire, this study adopted the convenience sampling in an investigation into those aging 20 or more in Taiwan and collected 760 valid copies. According to the results, there were significant differences in the intensity of five relation paths between those who had other APPLE products and those who did not. Specifically, (1) functional value had more significant positive effects on the path of consumer behaviors among those who did not have other APPLE products than among those who did; (2) epistemic value had more significant positive effects on the path of consumer attitudes among those who had other APPLE products than among those who did not; (3) conditional value had more significant positive effects on the path of consumer attitudes among those who did not have other APPLE products than among those who did; (4) emotional value had more significant positive effects on the path of consumers' purchase intention among those who had other APPLE products than among those who did not; (5) epistemic value had more significant negative effects on the path of consumers' purchase intention among those who had other APPLE products than among those who did not. The research results showed that there might be some differences in behavior model between the two groups. These results can serve as reference for practitioners in their making decisions on marketing.
\end{abstract}

Keywords: perceived value, consumer attitudes, purchase intention

\section{Introduction}

In the era featuring continual innovation in network technology, enterprises must constantly pursue innovation to survive and advance in the competitions brought by globalization. Mobile devices are the innovative products that have been developed in recent years. As the fast development and increasing popularity of mobile devices have created more business opportunities, those who have had mobile devices account for $80.8 \%$ of the total number of Taiwanese people (FIND, 2012). Thus this is an important target market that must be discussed.

Product innovation keeps enterprises competitive, so enterprises usually seek a vantage point by continually improving products or adding more functions and properties to products (Cooper \& Kleinschmidt, 1995). Nevertheless, the innovation and high-tech property of products would affect the purchase intention of consumers (Ziamous \& Ratneshwar, 2002). According to Chatterjee and Eliashberg (1990), when consumers were unfamiliar with innovative products, a higher level of uncertainty in the measurement of technology and quality would result in a lower level of consumer intention of purchasing these products. As highly innovative products may change the original way consumers used and understood products or may lead to differences in the decision on purchasing caused by the differences in the function, quality, efficacy and physical property of products, consumer innovativeness is an important factor that influences consumers' use of the products (Midgley \& Dowling, 1978). Therefore, consumers' purchase intention on innovation products is an important topic. 
Schiffman and Kanuk (2000) pointed out that the subjective cognition of consumers was based on consumers' understanding of innovative products rather than on the physical change to products or the response to products in the market. After summarizing the views on rationality and experience, Sheth, Newman and Gross (1991) proposed the Market Choice Theory. They assumed that consumers' perceived values promoted the selection of products and that it involved five value dimensions which was applicable to the consumption and selection of all products. The five dimensions were (1) functional value, (2) emotional value, (3) epistemic value, (4) social value and (5) conditional value. However, few people have discussed the influence of the five dimensions on the use of innovative products. Based on these five dimensions, this study aims to explore the impacts of consumers' perceived values on their purchase behaviors of innovative products.

According to the Photonics Industry and Technology Development Association (PIDA), the growth rate of the volume of delivered smart display devices across the world was $49.8 \%$. Take "smart watch" for instance. It captivates much attention for its features like lightness, thinness, power saving and flexibility and its smart functions like focus on health and sports. The smart watch developed by Apple Inc plays a leading role among smart watches. Moreover, the users of APPLE products tend to purchase other APPLE products or develop brand loyalty (Fishbein $\&$ Ajzen, 1975). Therefore, APPLE WATCH is selected be the subject of this research.

With the Market Choice Theory proposed by Sheth, Newman and Gross (1991) as the foundation and with relevant literature as the basis of the research framework, this study adopted the questionnaire survey to elaborate on the effects of functional value, emotional value, epistemic value, social value and conditional value on the attitude, purchase intention, and actual purchase behavior of consumers. Then, to compare the differences of relationship model between those consumers who had APPLE products and those who did not.

\section{Literature Review}

\subsection{Consumers' Perceived Values}

Sheth, Newman and Gross (1991) believed that consumers' behavior of purchase was mainly influenced by five value dimensions, namely, functional value, emotional value, epistemic value, social value and conditional value. This study is based on these five dimensions of consumers' perceived value: (1) functional value means that products or brands are endowed with some function, effectiveness or physical property and meet the objective of using the function; it is usually the most important factor that influences the selection and purchase of products; (2) emotional value focuses on if positive or negative emotions affect consumer attitude; (3) epistemic value indicates that products can arouse consumers' curiosity and attention or meet their desire for knowledge; (4) social value means that consumers can link themselves to other social groups through products or brands to achieve efficacy, obtain the approval of the social groups, meet social norms, reveal internal images, and display status or obtain a sense of belonging through the products; (5) conditional value indicates that external efficacy would appear under certain condition and change original behaviors and would be connected with the emotions of consumers. Here are the details:

\subsubsection{Functional Value}

Referring to customers' perception of the function, efficacy and property of products, it can be measured by consumers' perception of the functional value of products. The consumers' perception of functional value, which was proposed by Palmroth (1991), and the dimension of use value, which was put forward by Parasuraman and Grewal (2000), underlined the function, efficacy and property customers received in their use of products. Sheth, Newman and Gross (1991) came up with the value-based consumer behavior model and highlighted the function, efficacy and property of products. According to them, if a product had some functional value and met consumers' need of using the function, then the product was endowed with functional value. Based on the notion of functional value proposed by Palmroth (1991) and Sheth, Newman \& Gross (1991), this study employed function, efficacy and property as indicators to measure functional value.

\subsubsection{Emotional Value}

The consumer behavior model emphasizes a kind of feeling or an emotional state. If a product has the capability or efficacy of changing the feeling or emotion of consumers, it is endowed with emotional value (Sheth, Newman \& Gross, 1991). Consumers' emotional response to surroundings may have direct influence on their decision on consumption.

Mano and Richard (1993) argued that emotion was a cyclic organizational structure which was made up of two dimensions -- unpleasantness and arousal/quietness. The two dimensions can be further divided into positive emotion and negative emotion (Russell, 1987). Usually, such an emotional response is closely related to product experience 
and satisfaction (Mano \& Richard, 1993). Positive emotions like loyalty, nostalgia and excitement and negative ones like fear and guilt may create direct impact on the decision on consumption (Foxall \& Greenley, 1999). Creating a favorable atmosphere for consumption also has great effects in stimulating emotional response, and many non-textual clues may also become the factors that stimulate consumption (Hirschman \& Holbrook, 1982). According to the view of Russell (1987), this study used positive emotion and negative emotion as indicators to measure emotional value.

\subsubsection{Epistemic Value}

If a product meets consumers' curiosity, brings them something new or satisfies their need for new knowledge, then it has epistemic value. Normally the epistemic value of a product would attract consumer behavior if consumers are curious about the product or the product is novel, sophisticated and special (Zhang Wenyu, 2001). The consumers of such products usually take pleasure in trying something new, taking risk and seeking innovation (Sheth, Newman \& Gross, 1991). For instance, if the promotion of a product arouses consumers' curiosity and attracts their attention, they may purchase the product probably because it is new or popular. Usually, consumers of this kind would purchase a product merely because it is novel or popular (Schiffman \& Kanuk, 1991). Therefore, this study adopted the view on epistemic value of Sheth, Newman and Gross (1991) and took meeting curiosity and seeking new knowledge as indicators to measure epistemic value.

\subsubsection{Social Value}

Personal behavior is deeply affected by the entire surrounding. To obtain the approval of social groups and observe existing social norms, a person would try to form self image by consuming the features of products. Hence, if a product can connect consumers with other social groups and create efficacy, it is equipped with social value (Sheth, Newman \& Gross, 1991). Under the influence of social value, consumers do not give priority to the actual features or functions of products but attach importance to if products can raise their social statuses, shape their social images and satisfy their desires. Social value includes the value of pursuing identity, and consumers display their social statuses and abilities through products to gain approval in society and communities and obtain a sense of belonging. Leung (1998) demonstrated that consumers would distinguish social statuses and group participation and even strive for social approval through the acceptance of new technologies. In general, income, educational level and career are taken as indicators for differentiating social classes in society (Harrel, 1986), and different societies would lead to different kinds of consumption (Coleman, 1989). For example, a person in a high social class attaches more importance to if a product can show his/her prestige, status or class awareness rather than to its basic functions(Shaw, 1985). The consumption pattern is not only a kind of show-off but also a symbol of a person's identity and power and action consumers take to seek social approval. With the view on social value of Shaw (1985), this study used prestige, status and class as indicators to measure social value.

\subsubsection{Conditional Value}

Sheth, Newman \& Gross (1991) summarized the general features of condition with five dimensions, namely, physical surroundings, social surroundings, temporal perspective, task definition, and antecedent states. Conditions equip products with external efficacy, which would change consumers' current state and market selection. Basically, conditional value is not endurable but temporary. Under certain special condition, products can temporarily provide great functional or social value.

The features of conditional value include: (1) physical surroundings: it refers to apparent features like geographical location, atmosphere, lighting, sound, decoration, product form, product profile, and surroundings (Beker et al., 2002); (2) social surroundings: it indicates a person's social relations with others, including others who are present, their characteristics, interpersonal roles, and interpersonal interactions like the ones among colleagues and friends (Deshields et al., 1996); (3) temporal perspective: it bases measurement on the description of time or on relative time, such as the period between the current purchase and the previous one and the year, month, date and season of purchase; (5) antecedent states: it includes temporary emotions, including happiness, anxiety, hostility, wealth and physical condition. In this study, the five dimensions in the view on conditional value of Sheth, Newman and Gross (1991), physical surroundings, social surroundings, temporal perspective, task definition, and antecedent states, were taken as indicators to measure conditional value.

\subsection{Consumer Attitude}

Attitude refers to the positive and negative responses which are developed through learning (Assael, 1992). Fishbein and Ajzen (1975) believed that a person's attitude was retrieved from memory at certain time and under certain circumstance; attitude was a tendency of learning, through which a person developed emotional or appraisive 
response to what was observed. Kotler (1991) argued that attitude was a person's long-term love or hatred for some objects or concepts and his/her emotions and action tendency.

In this study, the views of Fishbein and Ajzen (1975) and Kotler (1991), which involve penchant and preference, were taken as indicators to measure consumer behavior.

\subsection{Purchase Intention of Consumers}

Purchase intention indicates consumers' subjective tendency for certain product, and it has been demonstrated that it can be used as an important indicator of predicting consumer behaviors (Fishbein \& Ajzen, 1975). The purchase intention of consumers refers to the possibility that consumers are willing to purchase certain product (Dodds et al., 1991; Schiffman \& Kanuk, 2000). The consumers who show a positive purchase intention will lead to a positive commitment, and commitment is consumers' desire of maintaining an essential relationship with manufacturers (Moorman et al., 1992) and will increase the possibility of consumers' purchase behavior of products (Schiffman \& Kanuk, 2000). Hence, the views of Moorman et al. (1992), which involve consideration of purchase, willingness and strenuous seeking, were taken as indicators to measure the purchase intention of consumers.

\subsection{Actual Purchase Behavior}

Engel, Kollat and Blackwell (1973) pointed out that purchase behavior referred to the direct behaviors of a person in his/her seeking and using economical products and services, including the decision-making that led to these behaviors. Williams (1982) believed that purchase behavior included a customer's physiological, psychological and emotional activities and his response and influence in his/her purchase of products and services. According to Schiffman and Kanuk (2000), the behaviors a consumer performed to meet his/her needs, including the seeking, purchasing, using, reviewing and handling of products, services and concepts, were called purchase behaviors. Kotler (2003) thought that the way individuals, groups and organizations selected, purchased, used and handled products, services, concepts or experience was called purchase behavior. With the view of Kotler (2003), this study defined actual purchase behaviors as the consumption behaviors of actual purchase and use of products, such as purchase and the determination to possess, and took them as indicators to measure actual purchase behaviors.

\subsection{Behavior Segment}

Kolter (2000) classified the variables of market segmentation into two groups. The first group was consumer feature, which included three variables, namely, geography, demographic statistics, and psychology; the second group was consumer response, which involved such behavioral variables as time of use, pursuit of interest, brand and loyalty. Consumer loyalty can be used to segment the behavioral variables to analyze the differences in the attitude towards new products and the purchase behavior of these products between existing customers and prospective ones. According to Wells (1975), gender, age, income, career, residence and other demographic statistical variables were often used to segment markets, but it could not reveal consumer features. Hence, this study, based on the view of behavioral variables, segmented consumers according to the criterion of possessing other APPLE products and reflected on the differences between those who had an APPLE product and those who did not.

\section{Research Hypothesis}

3.1 Influence of Consumers' Perceived Values (Functional Value, Emotional Value, Epistemic Value, Social Value, Conditional Value) on Consumer Attitude

The researches undertaken by Vinson, Scott, and Lamont (1977) and Kahle (1988) all showed that consumers' perceived values influenced consumer attitude and that the former was highly related to the latter. Therefore, attitude refers to consumers' positive or negative response at certain time, and consumers' perceived values would have influence on their attitude (Teas \& Agarwal, 2000). High consumers' perceived values would improve consumers' attitude towards products; if consumers maintain positive cognitive values for products, their attitude towards products would be more positive (Leppaniemi et al., 2004; Haghirian et al., 2005). According to the above literature, consumers' perceived values have positive effects on attitude. Hence, it can be inferred that the consumers' five perceived values for innovative products also has impacts on their attitude. For that reason, the following hypotheses were proposed:

H1: Consumers' perception of the functional value toward innovative products has significant positive influence on their attitude.

H2: Consumers' perception of the emotional value toward innovative products has significant positive influence on their attitude.

H3: Consumers' perception of the epistemic value toward innovative products has significant positive influence on 
their attitude.

H4: Consumers' perception of the social value toward innovative products has significant positive influence on their attitude.

H5: Consumers' perception of the conditional value toward innovative products has significant positive influence on their attitude.

3.2 Influence of Consumers' Perceived Values (Functional Value, Emotional Value, Epistemic Value, Social Value, Conditional Value) on Purchase Intention

Perceived values will influence person's media use and exposure (Becker \& Conner, 1981). Rose (1994) pointed out that value created effects on consumers' behaviors of purchasing popular products. Higher consumers' "perceived values" for products would lead to "stronger intention" of purchasing the products (Monroe \& Krishnan, 1985). Perceived values influence the net profits which consumers gain from their consumer behaviors; hence, "perceived values" are habitually regarded as an indicator of purchase intention, even in the paths in virtual lines (Chen \& Dubinsky, 2003). According to Sweeney and Soutar (2001), products and consumers' feeling about products should be taken as constituents of product value, and consumers' perceived values comprise emotional and social values. Keng and Yang (1993) investigated into the personal value and consumer behavior of the consumers in Taiwan and found that there was significant relevance between the two. Sheth (1991) believed that the five values that influenced the purchase intention of consumers made different contribution under different circumstances. Sometimes, consumers were influenced by only one value in the selection of products; in most cases, they may be influenced by at least two or even five values. It can be inferred from the above literature that the five consumers' perceived values for innovative products have influence on the purchase intention of consumers. Therefore, the following hypotheses were proposed:

H6: Consumers' perception of the functional value toward innovative products has significant positive influence on their purchase intention.

H7: Consumers' perception of the emotional value toward innovative products has significant positive influence on their purchase intention.

H8: Consumers' perception of the epistemic value toward innovative products has significant positive influence on their purchase intention.

H9: Consumers' perception of the social value toward innovative products has significant positive influence on their purchase intention.

H10: Consumers' perception of the conditional value toward innovative products has significant positive influence on their purchase intention.

\subsection{Influence of Consumers' Attitude on Their Purchase Intention}

Attitude is a person's long-term positive and negative remarks on objects or concepts and his/her emotions and action tendencies. It is a kind of response which can be developed from learning through such channels as media, the experience in product use, group learning, and internet (Kotler, 2000). Attitude is a main faith at certain time. In other words, attitude is a tendency of learning and a person's emotional or appraisive response to objects or concepts. Different from behavior, it can drive consumers to perform consumer behaviors; therefore, attitude has effects on the purchase intention of consumers (Fishbein \& Ajzen, 1975). It can be inferred from the above literature that consumers' attitude creates impacts on their purchase intention. Hence, the following hypothesis was proposed:

H11: Consumers' attitude toward innovative products has significant positive influence on their purchase intention.

\subsection{Influence of Consumers' Purchase Intention on Actual Purchase Behavior}

Consumers' behavior of purchasing innovative products depends on their purchase intention (Batte et al., 2007). Blackwell et al. (2006) thought that purchase intention was the product that consumers wanted to buy; William et al. (1991) believed that purchase intention was the possibility that consumers purchased products and the probability that they considered and were willing to purchase the products. According to Schiffman and Kanuk (2004), purchase intention measured the possibility that consumers purchased certain product. Previous studies on consumers' purchase behavior demonstrated that actual purchase was influenced by purchase intention (Shepherd et al., 2005). It can be inferred from the above literature that consumers purchase intention of innovative products have effects on actual purchase behavior. Therefore, the following hypothesis was proposed:

H12: Consumers' intention of purchasing innovative products has significant positive impacts on actual purchase 


\section{behavior.}

\subsection{Influence of the Possession of APPLE Products on the Full Relation Model}

Heskett, Sasser, and Hart (1989) pointed out that the cost for developing new customers was five times more than that for maintaining old ones. According to Reichheld and Sasser (1990), enterprises could increase their profits by $25 \%$ to $85 \%$ if they could reduce the customer attrition rate by at least $5 \%$. Therefore, it is very important for enterprises to constantly attract customers to purchase their products on a regular basis or purchase their new products. For that reason, whether the fact that consumers had APPLE products influences consumers' perceived values for new products and the relations among such dimensions as consumer attitude, purchase intention, and actual purchase behavior are the focuses of this study. In this study, consumers were divided into two groups, one of those who had other APPLE products and the other of those who did not, and emphasis was placed on the differences between the old consumers and the new. To this end, the following hypothesis was proposed:

H13: There are significant differences in path intensity between the group of those who had other APPLE products and the group of those who did not.

\section{Research Design}

\subsection{Research Framework}

The research architecture of this study was based on the research objective and relevant literature, and importance was attached to the influence of the five consumers' perceived values on consumer attitude, purchase intention and actual purchase behavior and to the differences between two groups. Meanwhile, APPLE WATCH was taken as the research target for the demonstration. Figure 1 shows the research framework.

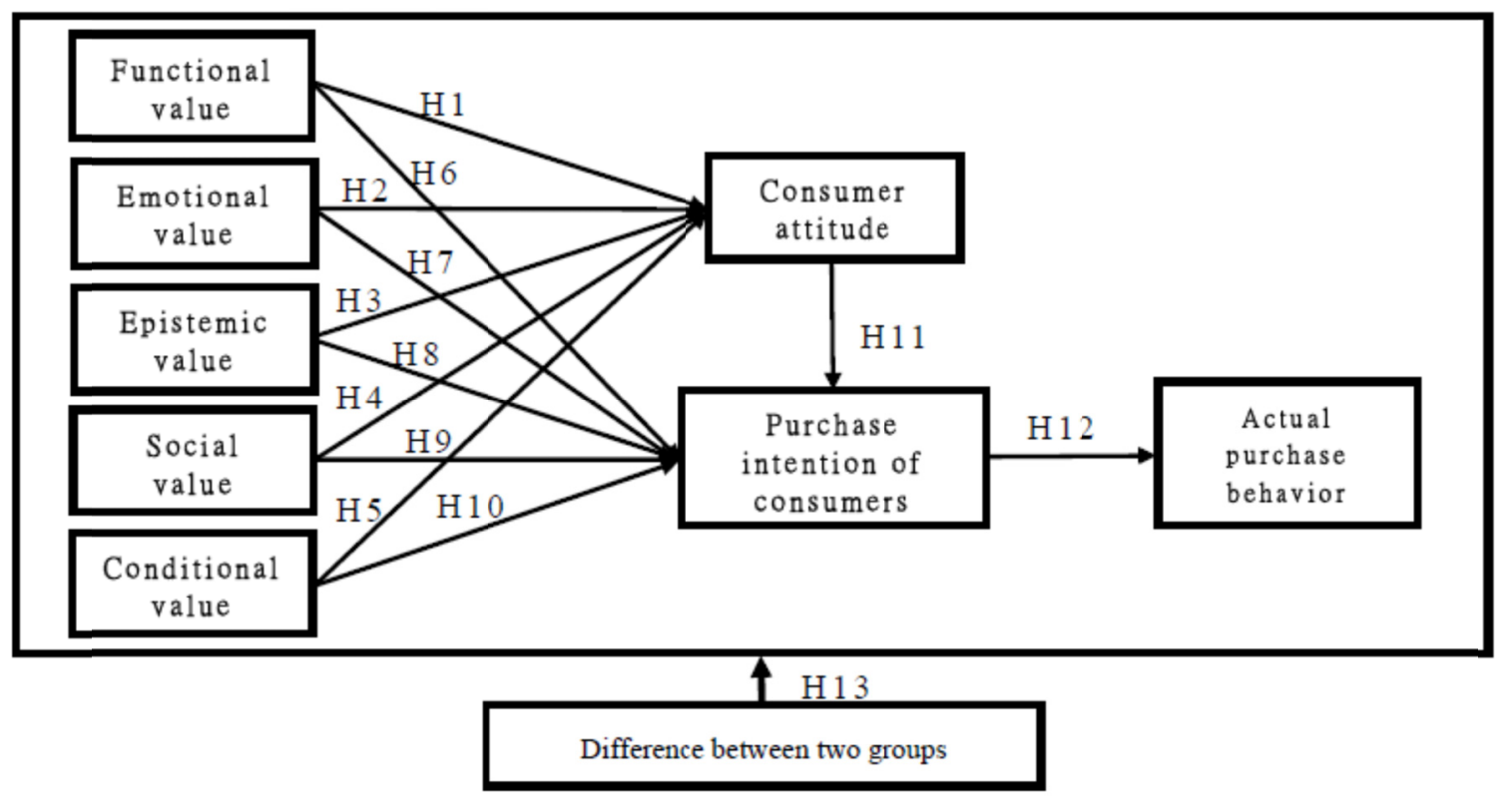

Figure 1. Research framework

\subsection{Pre-test and Pilot on Research Variables}

For the first step, this study designed the draft of questionnaire according to the above-mentioned theories and literature. Then, the interview method was adopted for the pre-test and improvement of the questionnaire, and the contents of the questionnaire were defined. After that, the questionnaire was used to collect information about the influence of consumers' perceived values for APPLE WATCH on the purchase behavior of innovative products. To obtain effective measurement tools, the questionnaire was improved in two stages -- pre-test and pilot. In the pre-test, the convenience sampling was used to select 30 people aging 20 or more in Taiwan for the questionnaire. The results showed hat some questions were not clear in meaning, so correction was done in this aspect. Then, the convenience sampling was adopted again to select 100 respondents as the samples of the pilot. Moreover, the filled copies were taken for the analysis of reliability and validity of questionnaire. According to the results of the pilot of the questionnaire, the Cronbach's $\alpha$ values of all measurement dimensions ranged from 0.709 to 0.968 , which met the 
criterion of over 0.7, indicating a high level of reliability (Nunnally, 1978). According to the results of factor analysis, the eigenvalue of all dimensions was above 1 , and all the cumulative explained variations were over 0.5 , while the factor loading of all variables exceeded 0.5 , indicating that all dimensions had the convergent validity (Kerlinger, 1978). Therefore, the questionnaire was an official one.

\section{Research Results}

\subsection{Sample Structure}

With the civilians aging 20 or more in Taiwan as the research subjects, this study adopted the convenience sampling to distribute 800 copies of questionnaire. Except the 40 invalid copies, 760 valid copies were retrieved, making up $95 \%$ of the total number of the copies. According to the analysis of sample distribution, male respondents accounted for $53.8 \%$ while female ones $46.2 \%$; those aging from 20 to 29 occupied $35.5 \%$, followed by those aging from 30 to $29(27.6 \%)$; those with a college education or a junior college education made up $62.4 \%$, followed by those with a high school education or a vocation education $(21.2 \%)$; in terms of career, those in the service industry accounted for $26.7 \%$, followed by those engaged in the manufacturing industry $(11.7 \%)$ and students $(10.5 \%)$; those with a monthly income ranging from NTD 10,000 to 30,000 made up $30.9 \%$, followed by those with a monthly income ranging from NTD 30,001 to 50,000 (30.3\%); those who surfed the Internet for 2 hours a day on average took up $59.3 \%$, the largest proportion; those who had other APPLE products made up $45 \%$.

\subsection{Analysis of Reliability and Validity of the Official Questionnaire}

After the official questionnaire, this study made an analysis of reliability and validity of all measurement dimensions, as is shown in Table 1. In this study, the Cronbach's $\alpha$ and the factor analysis were employed to evaluate the reliability and validity of questionnaire. According to Nunnally (1978), if a Cronbach's $\alpha$ value was over 0.7 , the questionnaire featured a high level of reliability; Kerlinger (1978) argued that the relevance coefficient of item to total needed to meet the criterion of over 0.5. The results showed that the Cronbach's $\alpha$ of all the dimensions and relevance coefficients in this study all met the criteria; therefore, the overall reliability of the questionnaire was high. In terms of validity, the factor analysis was used to test the convergent validity of questionnaire. According to Kaiser (1958), the eigenvalue of extraction factor must be over 1; the factor load of all variables of all factor dimensions must exceed 0.5 ; the cumulative explained variation must be over 0.5 . The results showed that the numerical values of all dimensions in this study were above or near the criteria, so the convergent validity of questionnaire was also high. Additionally, two indicators -- the composite reliability (CR) of potential variables and the average variance extracted (AVE) of potential variables -- were taken to evaluate reliability and validity, with the criterion that the CR value and the AVE value must be over 0.6 (Fornell \& Larcker, 1981). The CR values of the potential variables of all dimensions and factors of this study ranged from 0.9119 to 0.9817 , all of which were higher than 0.6 , indicating that the dimensions of this study featured a high level of internal consistency. Moreover, the AVE values of the potential variables ranged from 0.6744 to 0.9148 , all of which were higher than 0.6 and met the ideal results, indicating that all measurement items in the factor dimensions featured a high level of consistency, as is shown in Table 1.

Table 1. Analysis of reliability and validity of official questionnaire

\begin{tabular}{|c|c|c|c|c|c|c|c|c|}
\hline Factor & Mean & $\begin{array}{l}\text { Item-to-total } \\
\text { correlation } \\
\text { coefficient }\end{array}$ & $\begin{array}{c}\text { Factor } \\
\text { loading }\end{array}$ & $\begin{array}{l}\text { Eigenv- } \\
\text { alue }\end{array}$ & $\begin{array}{l}\text { Cumulative } \\
\text { Explained } \\
\text { Variation } \%\end{array}$ & $\begin{array}{c}\text { Cronbach } \\
\alpha \\
\text { value }\end{array}$ & $\begin{array}{c}\text { Compo- } \\
\text { nent } \\
\text { Reliabi- } \\
\text { lity } \\
\text { (CR) }\end{array}$ & $\begin{array}{l}\text { Average } \\
\text { Variance } \\
\text { Extracted } \\
\text { (AVE) }\end{array}$ \\
\hline \multicolumn{9}{|l|}{ Functional value (FuV) } \\
\hline $\begin{array}{l}\text { I think APPLE WATCH } \\
\text { is highly helpful for } \\
\text { health tracking. }\end{array}$ & 5.4500 & .854 & .906 & & & & & \\
\hline $\begin{array}{l}\text { I think APPLE WATCH } \\
\text { can effectively record } \\
\text { and monitor the amount } \\
\text { of exercise. }\end{array}$ & 5.5013 & .835 & .892 & 4.449 & 74.143 & .930 & 0.9449 & 0.7411 \\
\hline $\begin{array}{l}\text { I think APPLE WATCH } \\
\text { features a high level of } \\
\text { accuracy of } \\
\text { measurement. }\end{array}$ & 5.3513 & .827 & .887 & & & & & \\
\hline I think APPLE WATCH & 5.2763 & .774 & .843 & & & & & \\
\hline
\end{tabular}




\begin{tabular}{|c|c|c|c|c|c|c|c|c|}
\hline \multicolumn{4}{|l|}{$\begin{array}{l}\text { is a highly practical } \\
\text { product. }\end{array}$} & & & & & \\
\hline I think the & & & & & & & & \\
\hline $\begin{array}{l}\text { communication function } \\
\begin{array}{l}\text { of APPLE WATCH is } \\
\text { strong. }\end{array}\end{array}$ & 5.2553 & .769 & .840 & & & & & \\
\hline $\begin{array}{l}\text { I think APPLE WATCH } \\
\text { is highly wearable. }\end{array}$ & 5.2763 & .711 & .792 & & & & & \\
\hline \multicolumn{9}{|l|}{ Emotional value (EmV) } \\
\hline $\begin{array}{l}\text { The form of APPLE } \\
\text { WATCH makes me } \\
\text { happy. }\end{array}$ & 5.0000 & .772 & .890 & \multirow{4}{*}{2.889} & \multirow{4}{*}{72.234} & \multirow{4}{*}{.871} & \multirow{4}{*}{0.9119} & \multirow{4}{*}{0.7219} \\
\hline $\begin{array}{l}\text { APPLE WATCH gives } \\
\text { me expectation and } \\
\text { excitement. }\end{array}$ & 4.9303 & .766 & .887 & & & & & \\
\hline $\begin{array}{l}\text { don't think APPLE } \\
\text { WATCH is impractical. }\end{array}$ & 5.0697 & .729 & .847 & & & & & \\
\hline 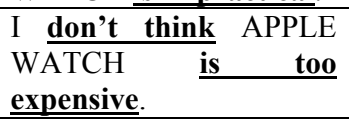 & 4.1395 & .618 & .769 & & & & & \\
\hline \multicolumn{9}{|l|}{ Epistemic value (EpV) } \\
\hline $\begin{array}{l}\text { APPLE WATCH is } \\
\text { something new. }\end{array}$ & 5.3987 & .841 & .916 & \multirow{4}{*}{3.186} & \multirow{4}{*}{79.658} & \multirow{4}{*}{.915} & \multirow{4}{*}{0.9400} & \multirow{4}{*}{0.7968} \\
\hline $\begin{array}{l}\text { APPLE WATCH can } \\
\text { arouse my curiosity and } \\
\text { desire for exploration. }\end{array}$ & 5.6237 & .801 & .890 & & & & & \\
\hline 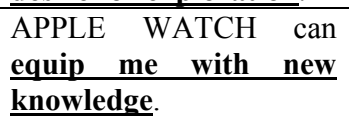 & 5.3066 & .793 & .884 & & & & & \\
\hline $\begin{array}{l}\text { APPLE WATCH can } \\
\text { give me an access to the } \\
\text { most innovative product } \\
\text { in the world. }\end{array}$ & 5.3408 & .786 & .880 & & & & & \\
\hline \multicolumn{9}{|l|}{ Social value (SoV) } \\
\hline $\begin{array}{l}\text { APPLE WATCH can } \\
\text { raise my social status. }\end{array}$ & 4.2579 & .939 & .960 & \multirow{6}{*}{5.065} & \multirow{6}{*}{84.412} & \multirow{6}{*}{.963} & \multirow{6}{*}{0.9701} & \multirow{6}{*}{0.8439} \\
\hline $\begin{array}{lll}\text { APPLE } & \text { WATCH } & \text { can } \\
\text { improve } & \text { my } \\
\text { interpersonal relations. }\end{array}$ & 4.3987 & .897 & .930 & & & & & \\
\hline $\begin{array}{l}\text { APPLE WATCH can } \\
\text { make me an intellect. }\end{array}$ & 4.1750 & .888 & .924 & & & & & \\
\hline $\begin{array}{l}\text { APPLE } \overline{\text { WATCH }} \text { can } \\
\text { reveal my wealth and } \\
\text { power. }\end{array}$ & 4.4671 & .875 & .913 & & & & & \\
\hline $\begin{array}{lcc}\text { APPLE WATCH } & \text { is a } \\
\text { symbol } & \text { of } & \text { great } \\
\text { economic power. } & \end{array}$ & 4.5276 & .850 & .895 & & & & & \\
\hline $\begin{array}{l}\text { APPLE } \text { WATCH can } \\
\text { earn me respect from } \\
\text { others. }\end{array}$ & 4.3211 & .840 & .888 & & & & & \\
\hline \multicolumn{9}{|l|}{ Conditional value (CoV) } \\
\hline $\begin{array}{l}\text { APPLE WATCH is } \\
\text { suitable for an official } \\
\text { occasion. }\end{array}$ & 4.5895 & .834 & .869 & \multirow{4}{*}{6.745} & \multirow{4}{*}{67.451} & \multirow{4}{*}{.946} & \multirow{4}{*}{0.9539} & \multirow{4}{*}{0.6744} \\
\hline 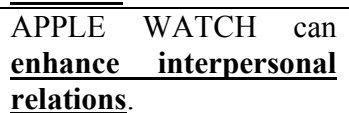 & 4.8105 & .815 & .855 & & & & & \\
\hline $\begin{array}{l}\text { APPLE WATCH is } \\
\text { suitable for a high-level } \\
\text { party. }\end{array}$ & 4.5132 & .806 & .846 & & & & & \\
\hline $\begin{array}{lr}\begin{array}{l}\text { APPLE } \\
\text { create }\end{array} & \begin{array}{r}\text { WATCH can } \\
\text { effective }\end{array}\end{array}$ & 5.3013 & .797 & .843 & & & & & \\
\hline
\end{tabular}




\begin{tabular}{|c|c|c|c|c|c|c|c|c|}
\hline \multicolumn{4}{|l|}{ communication. } & & & & & \\
\hline 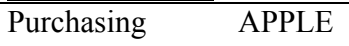 & & & & & & & & \\
\hline $\begin{array}{l}\text { WATCH makes me } \\
\text { happy. }\end{array}$ & 4.9026 & .787 & .830 & & & & & \\
\hline $\begin{array}{lll}\text { APPLE } & \text { WATCH } & \text { can } \\
\text { increase the topics } & \text { for } \\
\text { chatting. } & & \\
\end{array}$ & 5.2053 & .773 & .820 & & & & & \\
\hline 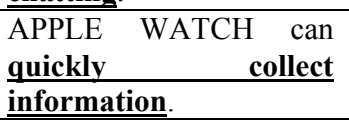 & 5.1763 & .761 & .812 & & & & & \\
\hline $\begin{array}{lrr}\begin{array}{l}\text { My friends } \\
\text { motivate }\end{array} & \text { would } \\
\text { me } & \text { to } \\
\text { purchase } & & \text { APPLE } \\
\text { WATCH. } & & \\
\end{array}$ & 4.3474 & .757 & .805 & & & & & \\
\hline $\begin{array}{l}\text { I can reward myself with } \\
\text { APPLE WATCH. }\end{array}$ & 5.4342 & .716 & .770 & & & & & \\
\hline $\begin{array}{l}\text { APPLE WATCH can be } \\
\text { used as a high-end gift. }\end{array}$ & 5.2500 & .700 & .755 & & & & & \\
\hline Consumer attitude (CA & & & & & & & & \\
\hline $\begin{array}{l}\text { I like the texture of } \\
\text { APPLE WATCH. }\end{array}$ & 5.0513 & .888 & .931 & \multirow{6}{*}{4.191} & \multirow{6}{*}{83.824} & \multirow{6}{*}{.952} & \multirow{6}{*}{0.9628} & \multirow{6}{*}{0.8382} \\
\hline I like the high & & & & & & & & \\
\hline $\begin{array}{l}\text { practicability of APPLE } \\
\text { WATCH. }\end{array}$ & 4.9645 & .883 & .927 & & & & & \\
\hline $\begin{array}{l}\text { I prefer to the design of } \\
\text { APPLE WATCH. }\end{array}$ & 4.9947 & .867 & .919 & & & & & \\
\hline $\begin{array}{l}\text { I would be fascinated by } \\
\text { APPLE WATCH. }\end{array}$ & 4.7737 & .860 & .910 & & & & & \\
\hline $\begin{array}{l}\text { I look forward to having } \\
\text { an APPLE WATCH. }\end{array}$ & 4.6671 & .831 & .890 & & & & & \\
\hline \multicolumn{9}{|c|}{ Purchase intention of consumers (CW) } \\
\hline $\begin{array}{l}\text { I would } \\
\text { purchasing an } \\
\text { WATCH. }\end{array}$ & 4.4724 & .917 & .948 & \multirow{5}{*}{4.361} & \multirow{5}{*}{87.213} & \multirow{5}{*}{.963} & \multirow{5}{*}{0.9622} & \multirow{5}{*}{0.8359} \\
\hline $\begin{array}{l}\text { There is high possibility } \\
\text { that I will purchase an } \\
\text { APPLE WATCH. }\end{array}$ & 4.2474 & .914 & .946 & & & & & \\
\hline $\begin{array}{l}\text { I am willing to purchase } \\
\text { APPLE WATCH to meet } \\
\text { my need. }\end{array}$ & 4.3750 & .898 & .935 & & & & & \\
\hline 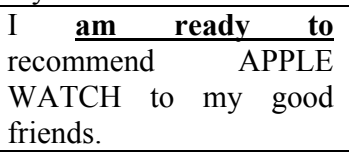 & 4.4079 & .884 & .926 & & & & & \\
\hline $\begin{array}{l}\text { I would try hard to seek } \\
\text { the information about } \\
\text { APPLE WATCH. }\end{array}$ & 4.5118 & .865 & .913 & & & & & \\
\hline \multicolumn{9}{|c|}{ Actual purchase behavior (FPB) } \\
\hline $\begin{array}{l}\text { I will purchase APPLE } \\
\text { WATCH as soon as } \\
\text { possible. }\end{array}$ & 3.9132 & .953 & .970 & \multirow{5}{*}{4.575} & \multirow{5}{*}{91.498} & \multirow{5}{*}{.977} & \multirow{5}{*}{0.9817} & \multirow{5}{*}{0.9148} \\
\hline $\begin{array}{l}\text { I promise to have an } \\
\text { APPLE WATCH. }\end{array}$ & 3.9329 & .941 & .962 & & & & & \\
\hline $\begin{array}{l}\text { It is highly likely that I } \\
\text { will purchase an APPLE } \\
\text { WATCH. }\end{array}$ & 4.2303 & .926 & .953 & & & & & \\
\hline $\begin{array}{l}\text { I will purchase an } \\
\text { APPLE WATCH in the } \\
\text { near future. }\end{array}$ & 3.6987 & .920 & .949 & & & & & \\
\hline $\begin{array}{l}\text { I promise to purchase } \\
\text { an APPLE WATCH in } \\
\text { the future. }\end{array}$ & 4.1303 & .918 & .948 & & & & & \\
\hline
\end{tabular}




\subsection{Confirmatory Factor Analysis (CFA)}

To demonstrate the efficiency of the measurement dimensions, this study adopted AMOS to make a confirmatory factor analysis (CFA) of the measurement model consisting of eight dimensions, namely, functional value, emotional value, epistemic value, social value, conditional value, consumer attitude, consumer intention, and actual purchase behavior.

According to the ideal model proposed by scholars, the construct validity should be measured with the following principles: the ratio of Chi-square value to degree of freedom in the adaptability indicators should be no more than 3 (Carmines \& MacIver, 1981; RMR (Root Mean Square Residual) and RMSEA (Root Mean Square Error of Approximation) should be lower than 0.05; GFI (Goodness of Fit Index), AGFI (Adjusted Goodness of Fit Index), NFI (Normed Fit Index), and CFI (Comparative Fit Index) should be higher than 0.9 (Bagozzi \& Yi, 1988; Joreskog \& Sorbom, 1989). Of the adaptability indicators of the entire measure model, as the results showed, $\chi^{2} / \mathrm{df}$ was 3.008 ; GFI, 0.879; AGFI, 0.845; NFI, 0.947; RFI, 0.935; CFI, 0.964; RMSEA, 0.051; RMR, 0.111. These indicators showed that the adaptability of the measurement model was not an ideal one but was still acceptable. It met the measurement criterion proposed by other scholars that GFI, AGFI, NFI and other indicators should be higher than 0.8 (Forza \& Filippini, 1998) and that CFI should be higher than 0.9 (Hair et al., 2006), so the adaptability of the model was consistent with the suggestion of the scholars; moreover, there was a significant relation among the question items and dimensions, which means that these measurement indicators are endowed with construct validity and measurement efficiency.

\subsection{Comparative Analysis of Competing Model between Groups}

In this study, the item of "Did you have other APPLE products" in the questionnaire was taken as the segment criterion for grouping the respondents. The results showed that 342 respondents had other APPLE products, accounting for $45 \%$, while 418 respondents did not, making up 55\%.

With AMOS, this study made a comparative analysis between two groups, with one consisting of those who had other APPLE products and the other comprising those who did not, with the hope of exploring the impacts of different groups on relation path. The adaptability of the competing model is shown in Table 2. It shows that all the adaptability indicators met the criterion that such indicators as GFI, AGFI and NFI should be higher than 0.8 (Forza \& Filippini, 1998); CFI, higher than 0.9 (Hair et al., 2006); RMSEA, lower than 0.05 (Brown \& Cudeck, 1993); $\chi^{2} / \mathrm{df}$, no more than 3 . Hence, the model was acceptable.

The results (see Table 2) of the analysis of competing model of the two groups are as follow:

(1). There was a significant difference $(\mathrm{t}=3.505)$ in the influence of functional value on consumer attitude (H1) between the two groups. Those who did not have other APPLE products had significant positive effects in the path, while those who did had significant negative effects in the path. This shows that the latter may have a higher expectation on the functional value of APPLE; therefore, the current functional value of APPLE does not have positive effects on the attitude of the group.

(2). There was no significant difference $(\mathrm{t}=-1.351)$ in the influence of emotional value on consumer attitude (H2) between the two groups. Those who did not have other APPLE products had significant negative effects in the path, while those who did had insignificant effects in the path. This demonstrates that a higher emotional value of those who did not have other APPLE products would lead to a more negative attitude. The phenomenon is worthy of a deeper discussion.

(3). There was a significant difference ( $\mathrm{t}=-2.849)$ in the influence of epistemic value on consumer attitude (H3) between the two groups. Those who had other APPLE products had significantly greater effects than those who did not. This means that the former has a stronger desire for something novel and new knowledge; hence, epistemic value has greater significant positive effects on its attitude.

(4). There was no significant difference $(t=-0.51)$ in the influence of social value on consumer attitude (H4) between the two groups. Neither of the two groups had significant effects in the path, which indicates that social value does not have significant effects on consumer attitude and that neither of them would show preference for new products even if the products can enhance their prestige, status and social class.

(5). There was a significant difference $(\mathrm{t}=2.532)$ in the influence of conditional value on consumer attitude (H5) 
between the two groups. Both groups had significant positive effects in the path, so the conditional value of APPLE had significant positive effects on consumer attitude, especially the group consisting of those who did not have other APPLE products. This demonstrates that favorable physical surroundings, social surroundings and temporal perspective would lead to more positive consumer response to new products.

(6). There was no significant difference $(\mathrm{t}=-0.41)$ in the influence of functional value on consumers' purchase intention (H6) between the two groups. Both groups had significant negative effects in the path, so the current functional value of APPLE does not have significant positive effects on consumers' purchase intention. Probably looking forward to better new products, consumers would check if the product met their expectation on function before developing purchase intention because of existing functions.

(7). There was a significant difference $(\mathrm{t}=-2.057)$ in the influence of emotional value on consumers' purchase intention (H7) between the two groups. Both groups had significant positive effects in the path, but those who had other APPLE products had greater effects in this path. This shows that consumers would develop purchase intention if they have positive emotions for new products.

(8). There was a significant difference $(\mathrm{t}=3.829)$ in the influence of epistemic value on consumers' purchase intention (H8) between the two groups. The group consisting of those who did not have other APPLE products had insignificant effects in the path, while the other group had significant negative effects in the path. This indicates that those who had other APPLE products would not develop purchase intention just to meet their curiosity or acquire new knowledge. Probably for the fact that they had used other APPLE products, they have greater expectation on products and thus look forward to greater innovation.

(9). There was no significant difference $(\mathrm{t}=1.772)$ in the influence of social value on consumers' purchase intention (H9) between the two groups. The group comprising those who had other APPLE products had insignificant effects in the path, while the other group had significant positive effects in the path. This manifests that those who did not have other APPLE products may develop purchase intention because of the high social value of APPLE.

(10). There was no significant difference $(t=-0.848)$ in the influence of conditional value on consumers' purchase intention (H10) between the two groups. The group comprising those who had other APPLE products had insignificant effects in the path, while the other group had significant positive effects in the path. This shows that those who did not have other APPLE products would not develop purchase intention because of a better condition.

(11). There was no significant difference $(\mathrm{t}=0.956)$ in the influence of consumer attitude on consumers' purchase intention (H11) between the two groups. Both groups had significant positive effects in the path. This means that consumer attitude has positive effects on the purchase intention of consumers.

(12). There was no significant difference $(\mathrm{t}=-0.304)$ in the influence of consumers' purchase intention on their actual purchase behavior (H12) between the two groups. Both groups had significant positive effects in the path. This demonstrates that consumers' purchase intention has positive effects on their actual purchase behavior.

(13). There were some significant differences in the relation path among the dimensions between the two groups, so H13 obtained some support.

According to what has been mentioned above, there were five significant differences in the relation path between the two groups, which means that the possession of other APPLE products indeed results in the difference in the relation structure of consumers' behavior of purchasing new products. This is a major finding of this study. 
Table 2. Analysis of the competing model of two groups

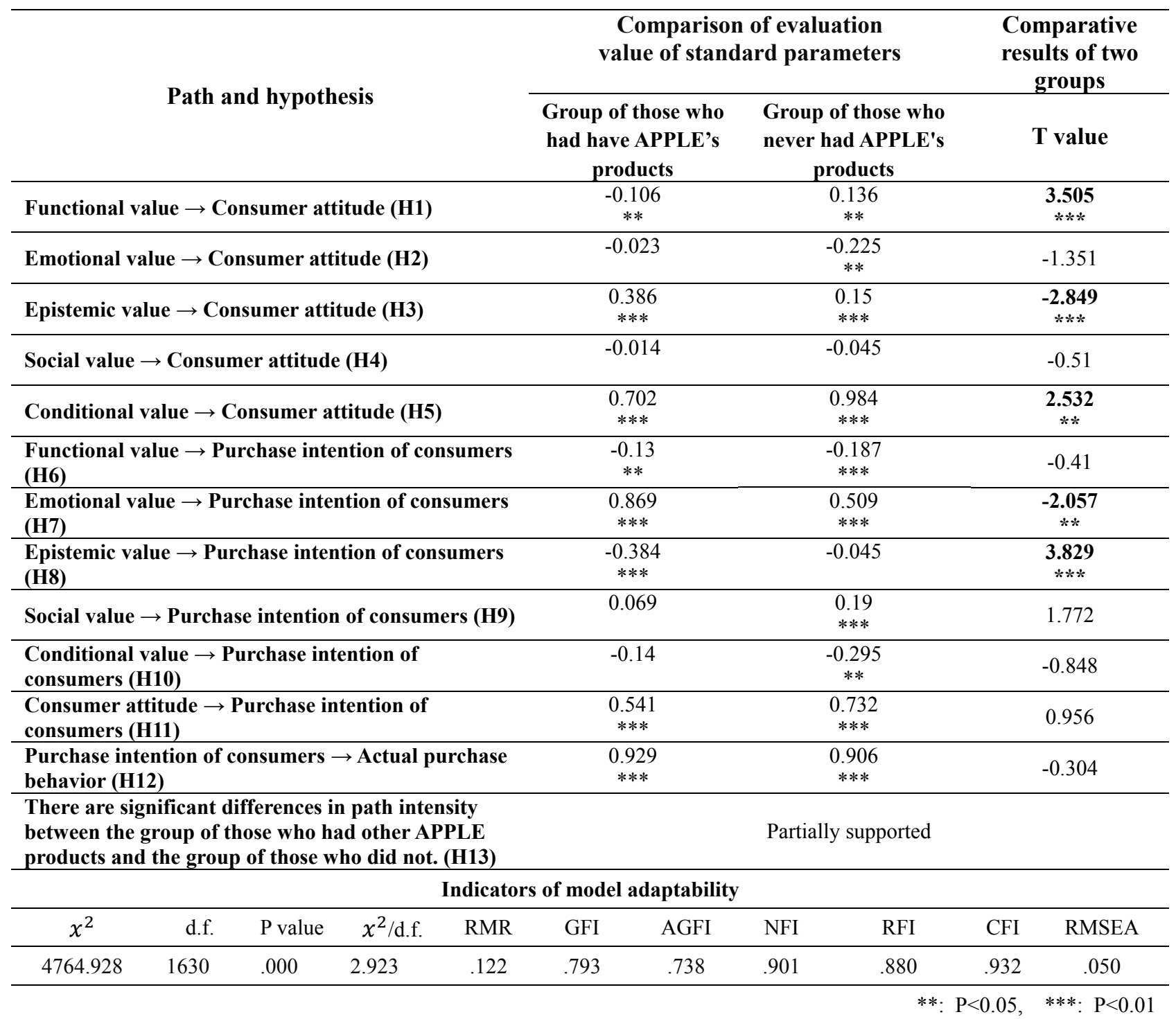

\section{Conclusion and Suggestions}

\subsection{Conclusion}

With those aging 20 or more in Taiwan as the research subjects, this study made a competing model analysis of two groups (one consisting of those who had other APPLE products and the other comprising those who did not), with the hope of finding out the differences in the relation intensity among such dimensions as the five perceived values of APPLE WATCH, consumer attitude, consumers' purchase intention and actual purchase behavior between the two groups. Apart from establishing a relation model among the dimensions, this study compared the two groups. The results of this study can serve as reference of conceptual architecture and research tool for the academic and industrial communities. Here are the results:

(1) As far as the influence of the five independent variables on consumer attitude is concerned, conditional value had great effects on consumer attitude for both groups. This means that the two groups would have a more positive attitude towards APPLE WATCH when they are influenced by favorable physical surroundings, social surroundings, temporal perspective, task definition and antecedent states. It is particularly true with those who did not have other APPLE products.

(2) So far as the influence of the five independent variables on purchase intention is concerned, emotional value had great effects on purchase intention for both groups. This indicates that both groups would have a stronger intention of 
purchasing APPLE WATCH if they show preference for APPLE, especially those who had other APPLE products.

(3) Consumer attitude had significant positive effects on purchase intention for both groups, which means that a positive attitude towards APPLE WATCH would be the most effective in enhancing consumers' intention of purchasing APPLE WATCH. Therefore, it is extremely critical to develop a positive attitude.

(4) Purchase intention had significant positive effects on actual purchase behavior for both groups, which indicates that a positive intention for APPLE WATCH would be the most effective in motivating the actual behavior of purchasing APPLE WATCH. Hence, how to strengthen consumer intention is a key topic.

\subsection{Managerial Implications}

With those aging 20 or more in Taiwan as the research subjects, this study discussed the relationship between consumers' perceived values and the behavior of purchasing new products. Aside from building a model of relations among the dimensions, it established efficient measurement variables, providing important research tools and relevant concepts for the academic and industrial communities. Therefore, it is of academic and practical significance.

According to the results, those who had other APPLE products might have greater expectation on the functional value of APPLE WATCH, so the current functions of APPLE WATCH cannot lead to consumers' positive attitude. Hence, brand is not the only factor consumers consider, and the functions of products need to be enhanced.

Therefore, the study suggests that relevant manufactures improve the functions of their products and further popularize their products through marketing, so as to enhance consumers' approval and understanding of the functional value of new products and develop a positive attitude, purchase intention and actual purchase behavior. Additionally, manufacturers should delve into the main factors that influence the attitude, purchase intention and actual purchase behavior of consumers. For instance, conditional and emotional factors help manufacturers plan the activities suitable for their new products and make marketing strategies; media or networks should be used to offer consumers relevant information and emphasize that new products can enhance interpersonal relations and pleasure, so as to promote consumers' purchase intention and actual purchase behavior.

According to the analysis of the competing models of the two groups, functional value had significant negative effects on consumers' attitude and purchase intention for those who had other APPLE products. This means that the APPLE users did not think that the function came up with their expectation and thus it could not enhance consumers' attitude, purchase intention and actual purchase behavior. However, conditional value had significant positive effects on them, so it is suggested that a purchase condition featuring high technology and value be established to strengthen positive emotions. For example, manufacturers should improve sale services, diversify the conditions of product usage, and focus on marketing strategies to meet consumers' expectation on emotion and conditional value.

For the two groups, conditional value had highly significant positive effects on consumer attitude, and emotional value created highly significant positive effects on consumers' purchase intention. Therefore, both emotional value and conditional value have great influence on the purchase intention and actual purchase behavior of new products. For both two groups, they are important marketing factors. Hence, manufacturers should place emphasis on the establishment of physical and social surroundings.

\subsection{Research Limitations and Suggestions for Future Studies}

In this study, the consumers in Taiwan were taken as the research subjects. However, these consumers are not the only people who have an access to new products, and the consumers in other countries may be different from that in Taiwan. For that reason, it is suggested that future researches cover a wide range to demonstrate the adaptability of the conceptual model in this study.

Additionally, different methods of marketing may influence consumers' attitude towards new products and their purchase intention and actual purchase behavior. Hence, deeper researches can be done on different brands or marketing models.

\section{References}

Assael, H. (1992). Consumer behavior and marketing action (4 $4^{\text {th }}$ ed.). Boston: PWS-Kent Publishing Company.

Becker, A. E., Burwell, D. B., Gilman, S. E., Rebecca, A., Hamburg, S., \& Herzog, P. (2002). Eating behaviours and attitudes following prolonged exposure to television among ethnic Fijian adolescent girls. Bnitish Joumal of Psychiatry, 180(6), 509-514. http://dx.doi.org/10.1192/bjp.180.6.509

Blackwell, R. D., Miniard, P. W., \& Engel, J. F. (2005). Consumer behavior (10th ed.). Boston, MA: South Western 
College Pub.

Chatterjee, R., \& Eliasberg, J. (1990). The innovation diffusion process in a heterogeneous population: A micromodeling approach. Management Science, 36(9), 1057-1079. http://dx.doi.org/10.1287/mnsc.36.9.1057

Coleman, R. W. (1989). A perceived risk analysis of patient choice of provider setting for dental services. D. B. A, Louisiana Tech University. http://dx.doi.org/10.1111/j.1749-6632.2001.tb03918.x

Cooper, R. G., \& Kleinschmidt, E. J. (1995). Benchmarking the firm's critical success factors in new product development. Journal of Product Innovation Management, 12(5), 374-391. http://dx.doi.org/10.1016/0737-6782(95)00059-3

DeShields, T. L., McDonough, E. M., Mannen, R. K., \& Miller, L. W. (1996). Psychological and cognitive status before and after heart transplantation. General Hospital Psychiatry, 18(6), 62-69. http://dx.doi.org/10.1016/S0163-8343(96)00078-3

Dodds, W. B., Monroe, K. B., \& Grewal, D. (1991). Effects of price, brand, and store iformation on buyers'product evaluations. Journal of Marketing Research, 28(3), 307-319. http://dx.doi.org/10.2307/3172866

Engel, J. F., Kollat, D., \& Blackwell, R. D. (1982). Consumer behavior. Chicago: Dryden.

Engle, J. F., Kollat, D., \& Blackwell, R. D. (1973). Consumer behavior (2th ed.). New York., Holt, Rinehart and Winston Inc.

Fishbein, M., \& Ajzen, I. (1975). Belief, attitude, intention, and behavior: An introduction to theory and research reading. MA: Addison-Wesley.

Foxall, G. R., \& Greenley, G. E. (1999). Consumers' emotional responses to service environments. Journal of Business Research, 46(2), 58-149. http://dx.doi.org/10.1016/S0148-2963(98)00018-6

Haghirian, P., Madlberger, M., \& Tanuskova, A. (2005). Increasing advertising value of mobile marketing:an empirical study of antecedent. In proceedings of the $38^{\text {th }}$ Hawaii International Conference on System Sciences. http://dx.doi.org/10.1109/HICSS.2005.311

Harrel, G. D. (1986). Consumer Behavior. Harcourt Brace Jovanovich ,Publishers.

Heskett, J. L., Sasser, W. E., \& Hart, C. W. (1989). Service breakthrough. New York: The Free Press.

Hirschman, E. C. (1980). Innnovativeness, novelty seeking and consumer creativity. Journal of Consumer Research, 7(3), 283-295. http://dx.doi.org/10.1086/208816

Hirschman, E. C., \& Holbrook, M. B. (1982). Hedonic Consumption: Emerging concepts, methods and propositions. Journal of Marketing, 46(3), 92-101. http://dx.doi.org/10.2307/1251707

Howard, J. A. (1994). Buyer behavior in marketing strategy (2th ed.). Englewood Cliffs, N.J. Prentice-Hall Inc.

Kahle, L. R., \& Kennedy, P. (1988). Using the list of value (LOV) to understand consumers. Journal of Services Marketing, 2(4), 49-56. http://dx.doi.org/10.1108/eb024742

Kotler, P. (1991). Marketing management: analysis, planning, implementation and control ( $7^{\text {th }}$ ed.). Upper Saddle River, NJ: Prentice-Hall.

Kotler, P. (1997). Marketing management: Analysis, planning, implementation, and control (9th ed.). New Jersey: Prentice Hall.

Kotler, P. (2003). A framework for marketing management (6th ed.). Prentice Hall, N.J.

Kotler, P., Ang, S. H., Leong, S. M., \& Tan, C. T. (1999). Marketing management: An asian perspective. Singapore: Prentice Hall.

Leppäniemi, M., Karjaluoto, H., \& Salo, J. (2004). The success factors of mobile advertising value chain. EBusiness Review IV, 93-97. http://dx.doi.org/10.1504/IJMDM.2005.005966

Leung, L. (1998). Lifestyle and the use of new media technology in urban china. Telecommunication Policy, 22(9), 787-790. http://dx.doi.org/10.1016/S0308-5961(98)00055-X

Mano, H., \& Richard L. O. (1993). Assessing the dimensionality and structure of the consumption experience: Evaluation, feeling, and satisfaction. Journal of Consumer Research, 20(12), 451-466. http://dx.doi.org/10.1086/209361

Midgley, D. F., \& Dowling, G. R. (1978). Innovativeness: The concept and its measurement. Journal Of Consumer 
Research, 4(4), 229-242. http://dx.doi.org/10.1086/208701

Moorman, C., Zaltman, G., \& Deshpande, R. (1992). Relationships between providers and users of market research: The dynamics of trust within a between organizations. Journal of_Marketing Research, 9(3), 17-328. http://dx.doi.org/10.2307/3172742

Nicholas, J., \& Ledwith, A. (2006). Development of a best practices framework in small to medium enterprises. The 14th Annual High Technology Small Firms Conference, University of Twente, Enschede, The Netherlands.

Palmroth, W. (1991). Always remember the six buyer benefits; qualiities buyers look for in a product. American salesman, 36(9), 12-18.

Parasuraman, A., \& Grewal, D. (2000). The impact of technology on the quality-value-loyalty chain: A research agenda. Academy of Marketing Science Journal, 28(1), 168-174. http://dx.doi.org/10.1177/0092070300281015

Peter, J. P., \& Olson, J. C. (2001). Consumer behavior. Irwin, Chicago, IL.

Reichheld, F. F., \& Sasser, W. E. (1990). Zero defections: Quality comes to service. Harvard Business Review, 68, 105-111. http://dx.doi.org/10.1002/npr.4040150312

Rogers, E. M. (1995). Diffusion of Innovations. New York: Free Press.

Russell, R. V. (1987). The importance of recreation satisfaction and activity participation to the life satisfaction of age-segregated retires. Journal of Leisure Research, 19(4), 273-283. http://dx.doi.org/10.1080/01490408709512159

Schiffman, L. G., \& kanuk, L. L. (1991). Consumer behavior. Prentice Hall, New Jersey.

Schiffman, L. G., \& Kanuk, L. L. (2000). Consumer behavior. Prentice Hall International, Inc.

Schiffman, L. G., \& Kanuk, L. L. (2000). Consumer behavior. Upper Saddle River, N.J: Prentice Hall.

Schiffman, L.G., \& Kanul, L. L. (2000). Consumer behavior (7th ed.). New Jersey, Prentice-Hall Inc.

Shaw, S. (1985). The meaning of leisure in everyday life. Leisure Sciences, 7(1), 1-24. http://dx.doi.org/10.1080/01490408509512105

Sheth, N. J., Newman I. B., \& Gross, L. B. (1991). Consumption values and market choices: Theory and applications. Cincinnati, OH: Southwestern Publishing.

Sheth, J. N., Newman, B. I., \& Gross, B. L. (1991). Why we buy what we buy: A theory of consumption value. Journal of Business Research, 22(1), 159-170. http://dx.doi.org/10.1016/0148-2963(91)90050-8

Teas, Kenneth R., \& Sanjeev A. (2000). The influence of extrinsic product cues on consumers' perceptions of quality, sacrifice, value. Journal of the Academy of Marketing Science, 28(2), 278-290. http://dx.doi.org/10.1177/0092070300282008

Vinson, D. E., Scott, J. E., \& Lamont, L. H. (1977). The role of personal values in marketing and consumer behavior. Journal of Marketing, 41(2), 44-50. http://dx.doi.org/10.2307/1250633

Wells, W. D. (1975). Comment on the Meaning of LifeStyle, in Advances in Consumer Research, ed. Beverlee B. Anderson, Ann Arbor. MI: Association for Consumer Research.

Williams, T. G. (1982). Consumer behavior fundamental and strategies. St.Paul Minn:West Publishing Co.

Zeithaml, V. A. (1988). Consumer perceptions of price, quality and value: A mean-end model and synthesis of evidence. Journal of Marketing, 52(3), 2-22. http://dx.doi.org/10.2307/1251446

Zeithaml, V. A., Berry, L., \& Parasuraman, A. (1996). The behavioral consequences of service quality. Journal of Marketing, 60(2), 31-46. http://dx.doi.org/10.2307/1251929

Ziamou, P., \& Ratneshwar, S. (2002). Promoting consumer adoption of high-technology products: Is more information always better?. Journal of Consumer Psychology (Lawrence Erlbaum Associates), 12(4), 341-351. http://dx.doi.org/10.1207/15327660260382379 